\title{
A rare heteromorphism of chromosome 20 and reproductive loss
}

\author{
D R Romain, S Whyte, D F Callen, H J Eyre
}

\begin{abstract}
A rare centromeric heterochromatic variant of chromosome 20 was encountered during investigations in a couple with repeated miscarriages. The enlarged segment was $G$ and $C$ band positive and stained positively by Giemsa II. In situ hybridisation of the biotinylated alphoid probe $D 20 Z 1$ specific for the centromere of chromosome 20 to metaphase cells confirmed the presence of amplified sequences adjacent to the centromere. The variant was found to be familial and was evaluated as having no clinical significance.
\end{abstract}

We have used, in addition to well established banding techniques, in situ hybridisation with the biotinylated probe $\mathrm{D} 20 \mathrm{Z1}$ to evaluate an uncommon heteromorphism observed in the centromere region of chromosome 20. Differences in fluorescent intensity for this region have been described, ${ }^{12}$ but only rarely when heterochromatin has extended into either the long or short arm or both. ${ }^{3}$

\section{Materials and methods}

CYTOGENETICS

Chromosomes were obtained from PHA stimulated lymphocyte cultures and investigated by routine $\mathrm{C}$,

Cytogenetics Laboratory, Laboratory Services, Wellington Hospital, Wellington, New Zealand.

D R Romain

Cytogenetic Laboratory, Memorial Hospital, Hastings, New Zealand.

S Whyte

Department of Cytogenetics and Molecular Genetics, Adelaide Children's Hospital, North Adelaide, South Australia.

D F Callen, H J Eyre

Correspondence to Mr Romain.

Received for publication 12 November 1990.

Accepted for publication 29 November 1990.
GTG, Giemsa II, and high resolution G banding techniques.

\section{PROBE}

The $\alpha$ satellite repetitive probe $\mathrm{D} 20 \mathrm{Z} 1$ is specific for the centromere region of chromosome $20^{4}$ and was obtained from Oncor Inc Gaithersberg MD.

\section{HYBRIDISATION}

Hybridisation was for 17 hours at $37^{\circ} \mathrm{C}$ in a humid chamber with a probe concentration between $1 \mathrm{ng} / \mu \mathrm{l}$ and $2 \mathrm{ng} / \mu \mathrm{l}$. Washing of the slides and the detection and amplification of the hybridised biotinylated probe were a modification of the technique of Burns et al, ${ }^{5}$ described in detail in Callen et al. ${ }^{6}$

\section{Case report}

A 32 year old male and 18 year old female were referred for chromosomal studies as part of investigations for three first trimester miscarriages. $G$ and

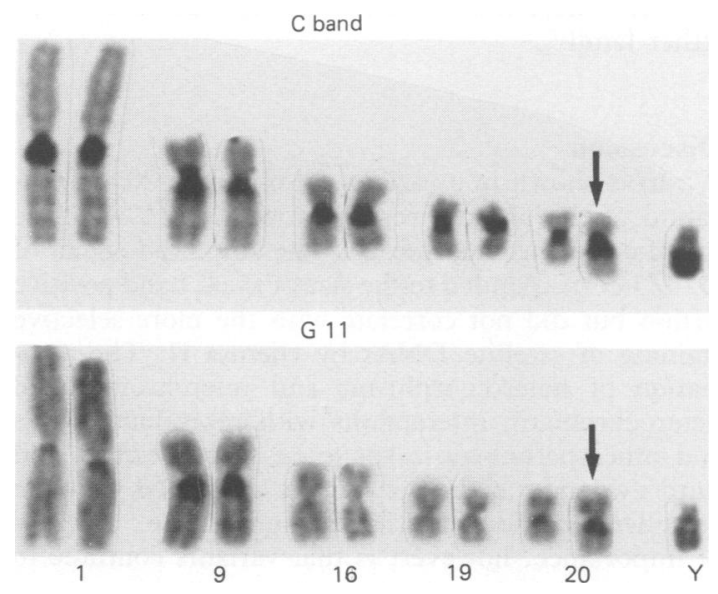

Figure I C banding and Giemsa II staining showing the variant chromosome 20. 


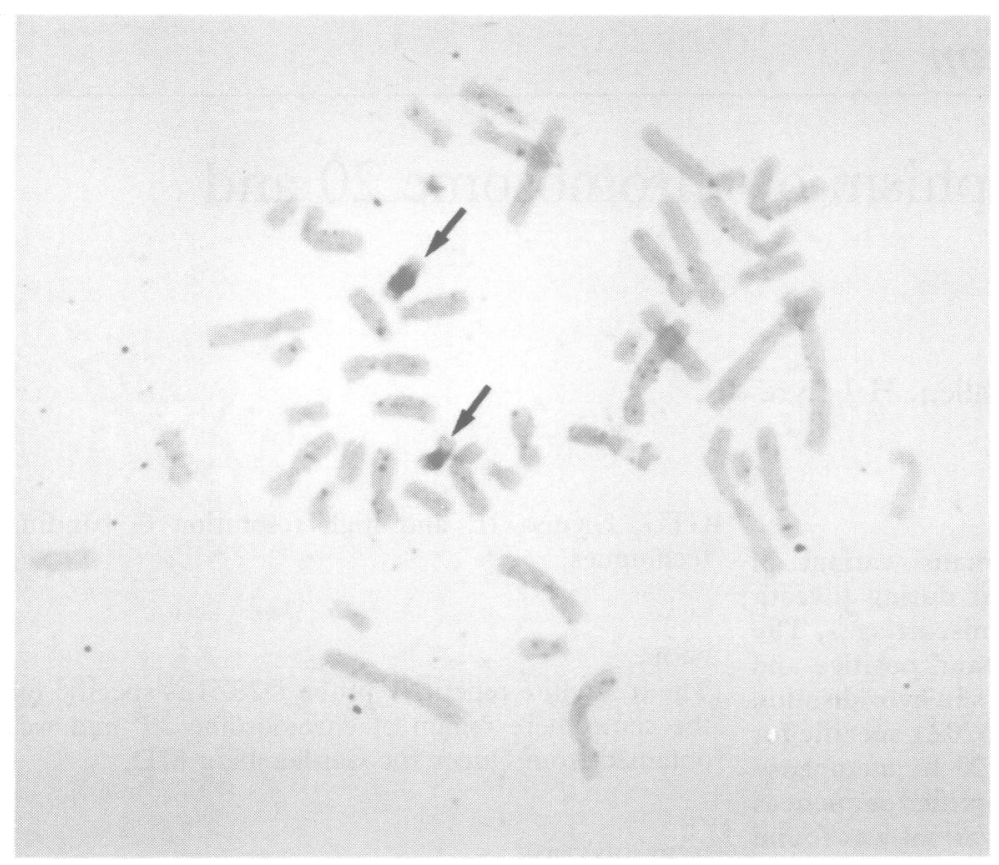

Figure 2 Metaphase spread after in situ hybridisation with the probe D20Z1 showing signal specific to chromosome 20.

HRG banding techniques showed normal chromosomes except for variation in the centromere region of one chromosome 20 in the male. $\mathrm{C}$ banding showed positive staining extending into both the short and long arms (fig 1) while Giemsa II staining was seen only in the long arm (fig 1). In situ hybridisation of the probe D20Z1 to metaphase chromosomes confirmed the presence of tandemly repeated alphoid DNA (fig 2). Extended chromosome studies showed the variant to be present in the male patient's mother. There was no history of reproductive loss in either family.

\section{Discussion}

We have shown in a variant chromosome 20 amplification of the alphoid repeat probe D20Z1 which is specific for chromosome 20 . The amplified signal of D20Z1 corresponded to the size of the $\mathrm{C}$ band positive region but did not correlate with the more selective staining of satellite DNAs by Giemsa II. The association of heteromorphisms and interchromosomal heterochromatin interactions with reproductive loss and other pathology is yet to be substantiated, and until evidence to the contrary is presented they are considered to be of no clinical significance. ${ }^{7}$ What is of importance, however, is that variants continue to be reported and structurally resolved for purposes of genetic counselling, prenatal diagnosis, and frequency in the population. ${ }^{3}$ We thus consider this heteromorphism in chromosome 20 to be a normal familial variant with no pathological significance.

We would like to thank Mrs $\mathrm{H}$ Lawton for typing this manuscript and the Audio Visual Unit, Wellington Public Hospital for help with the illustrations.

1 McKenzie WH, Lubs HA. Human $Q$ and C chromosomal variations: distribution and incidences. Cytogenet Cell Genet 1975;14:97-115.

2 Nakagome Y, Oka S, Matsunaga E. LBA technique in the detection of chromosome variants. II. Chromosomes except for those with Q variants. Hum Genet 1977;38:307-14.

3 Petersen MB. Rare chromosome 20 variants encountered during prenatal diagnosis. Prenat Diagn 1986;6:363-7.

4 Waye JS, Greig G, Duffy SJ, England SB, Warburton PW, Willard HF. Molecular and genetic characterisation of chromosome specific subsets of human satellite DNA. Cytogenet Cell Genet 1987;46:712.

5 Burns J, Chan VTW, Jonasson JA, Fleming KA, Taylor S, McGee OD. Sensitive system for visualising biotinylated DNA probes hybridised in situ: rapid sex determination of intact cells. F Clin Pathol 1985;38:1085-92.

6 Callen DF, Ringenbergs ML, Fowler JCS, Freemantle CJ, Haan EA. Small marker chromosomes in man: origin from pericentric heterochromatin of chromosomes 1, 9 and 16. 7 Med Genet 1990;27:155-9.

7 Gardner RJM, Sutherland GR. Chromosome abnormalities and genetic counselling. Oxford: Oxford University Press, 1989. 